Pro-social and aggressive behaviors among school children: The role of callous-unemotional traits

\author{
Nwafor, Chidozie E. $\$ \\ Department of Psychology, Nnamdi Azikiwe University, Awka, Nigeria (ce.nwafor@unizik.edu.ng) \\ Anazonwu, Charles Okechukwu \\ Department of Psychology, Nnamdi Azikiwe University, Awka, Nigeria (co.anazonwu@unizik.edu.ng) \\ Okafor, Okechukwu Chiedozie \\ Department of Political Science/Psychology/Sociology, Federal University Ndufu-Alike, Ikwo, Nigeria \\ (chiedozie.okafor@funai.edu.ng) \\ Obi-Nwosu, Harry \\ Department of Psychology, Nnamdi Azikiwe University, Awka, Nigeria (ho.nwosu@ unizik.edu.ng)
}

Received: 23 August 2016

Available Online: 1 October 2016

Revised: 5 September 2016 DOI: $10.5861 /$ ijrsp.2016.1613

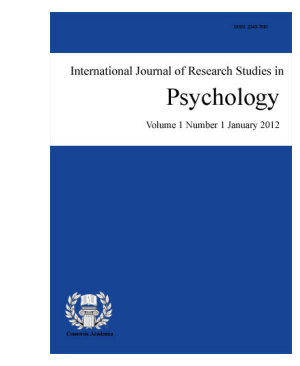

ISSN: $2243-7681$ Online ISSN: 2243-769X

OPEN ACCESS

\title{
Abstract
}

Different kinds of behavior and traits may gradually manifest during the childhood; among such behaviors are pro-social and aggressive behaviors. The present study examined two developmental traits (callous-unemotional) and their role in the relationship between pro-social and aggressive behavior. Participants are school pupils in Nkpor; a South Eastern town in the Anambra State of Nigeria. All the participants were of the Igbo ethnic group. They include 65 primary school pupils comprising of 30 primary six pupils $\left(M_{\text {age }}=10.50, S D=\right.$ $1.07)$ and 35 primary two pupils $\left(M_{\text {age }}=6.02, S D=.66\right)$. Data for pro-social, aggressive behavior and callous-unemotional traits $(\mathrm{CU})$ were gathered from the teacher's report. Results revealed that $\mathrm{CU}$ traits were negatively correlated with pro-social but positively correlated with aggression. Pro-social behavior was also negatively correlated with aggressive behavior. Hierarchical regression showed that pro-social behavior was not a significant predictor of aggressive behavior when CU traits were not controlled, while CU traits predict aggressive behavior with or without pro-sociality. The discussion focused on callous and uncaring traits as an important mediating mechanism that could help researchers understand early developmental trajectories of pro-social behaviors.

Keywords: pro-social; aggressive; callous-unemotional traits; childhood; behavior 


\section{Pro-social and aggressive behaviors among school children: The role of callous-unemotional traits}

\section{Introduction}

Most societies attach great values to the upbringing and general well-being of their children. This is because children are the hope for the continual existence of the future society (Ibeagha, 2006). The qualities of upbringing received by the children (e.g. conduciveness of the environment and other child rearing experiences) are known factors that create balance or imbalance in the children's psychological, cognitive, emotional and social domain development (Amato \& Cheadle, 2008; Dwairy, 2009; Grusec, 2011; McLeod, Weisz, \& Wood, 2007; Rothbaum \& Weisz, 1994). Some social psychologists and specialists in other allied disciplines have used social and anti-social classifications to describe many cognitive, affective and behavioral manifestations. The cognitive and behavioral manifestations though very important, cannot be investigated in a single study. The present study seeks to understand the developmental trajectory of two independent characteristics: pro-social and aggressive behaviors by exploring the extent pro-social behavior will predict aggressive behavior when callous-unemotional traits are not controlled.

Generally, pro-social behaviors (i.e. actions such as comforting or assisting, sharing and volunteerism that benefit others) are deemed desirable and beneficial to society (Eisenberg, Fabes, \& Spinard, 2006; Carlo, Knight, McGinlay, Zamboanga, \& Jarvis, 2010). Pro-social behavior can be stable over time and can also activate the potential in children, which can enable them to navigate and cope with the daily developmental task within the accepted social values and norms (Cassidy, Werner, Rourke, Zubernis, \& Balarman, 2003; Eisenberg et al., 1996; Gill \& Calkins, 2003). Contrary, aggressive behaviors (actions such as physical, relational or verbal abuse, or harm to self or others) are markers of social incompetence. It tends to activate the inability to navigate and cope with the daily developmental task within the acceptable social norms (Nwafor, Onyeizugbo, \& Anazonwu, 2015; O'Campo, Burke, Peak, \& Gielen, 2005). Evidence has shown that the development and maintenance of these opposing behaviors (pro-social and aggressive) are traceable to the childhood (Kokko, Tremblay, Lacourse, Nagin, \& Vitaro, 2006; Wildeboer et al., 2015).

Longitudinal studies have also shown that the significant present of either behavior during childhood can be a potent indicator that the child will manifest such behavior during adolescence and adulthood (Hughes \& Dunn, 2000; Wildeboer et al., 2015). However, the difference is that pro-social behaviors are desirable and can predict positive outcomes such as buffering the effects of aggression, promoting positive peer interrelationship and other social competencies (Clark \& Ladd, 2000; de Guzman \& Carlos, 2004). On the other hand, aggressive behaviors are undesirable and are associated with negative outcomes (dropout from school, high risk for future police / judicial contacts and very poor academic performance (Ferdinard, Van der Ende, \&Verhulst, 2007; Hodges \& Perry, 1996, Perry, Hodges, \& Egan, 2001). Only a few studies have considered the relationship between pro-social and aggressive behavior in children (Caprara, Barbaranelli, \& Pastorelli, 2001; Diener \& Kim, 2004; Flynn, Ehrenreich, Beron, \& Underwood, 2015; Nantel-Vivier, Pihl, \& Trembla, 2010; Nelson \& Crick, 1999) and they found that pro-sociality is negatively related to aggressive behavior.

One of the ways of understanding the negative relationship between pro-social behavior and aggression was demonstrated in the work of Penner, Fritzsche, Craigner, and Freifeld (1995) that developed the pro-social personality battery and suggested that some traits correlate positively with pro-sociality. Following the lead (Eisenberg et al., 1999; Flynn et al., 2015) further show that preschool dispositions emerge in early childhood and remain moderately consistent into young adulthood. Some traits are, however labeled Psychopathic (e.g. callousness, unemotional and uncaring) and have been associated with aggression, shallow affect and lack of empathy (Hare \& Neumann, 2008; Porter \& Woodworth, 2006) factors known to be negatively related to pro-social behavior (Flynn et al., 2015). Thus, another factor considered in this study is callous-unemotional 
Pro-social and aggressive behaviors among school children: The role of callous-unemotional traits

traits (CU). CU is described as specific deficits in affect (e.g. Lack of empathy and guilt, failure to put the effort on important tasks, shallow and deficient emotions) which are relatively stable across childhood into adolescence when compared to other measures of childhood personality (Frick, Ray, Thornton, \& Kahn, 2014; Nwafor et al., 2015). The assessment of CU traits can either be one dimensional (summing the subscales) or multi-dimensional (treating the subscales as independent factors). The three subscales of CU traits include Callousness (absent of guilty or remorsefulness); uncaring (not being concerned about the welfare or feeling of others); unemotional (not expressing or letting out one's emotion). $\mathrm{Cu}$ traits have been found to be positively related with aggression (Nwafor et al., 2015); increased the severity of aggression (Kahn et al., 2012) and negatively related to callousness (Flynn et al., 2015).

\subsection{Present Study}

The previous studies have established that pro-social behavior and aggressive behaviors are negatively related thus suggesting that pro-sociality may have a significant buffer effect on aggression (Flynn et al., 2015; Nantel-Vivier, 2010). It has also been established that CU traits and aggression was positively related thus suggesting that CU traits may significantly potentiate or trigger aggressive behavior (Frick, Ray, Thornton, \& Kahn, 2014; Kahn et al., 2012; Nwafor et al., 2015). Pro-social behavior is negatively related to CU traits (Flynn et al., 2015; White, 2013) thus may have a cushion effect on CU traits. The present study, therefore, investigates whether the relationship between pro-sociality and aggressive behavior will still be significant if CU traits are not controlled. The first drive is that some studies (Gao \& Raine, 2010; Hawley, 2003; McGinley \& Carlo, 2006) have suggested that some individual can be equal pro-social and aggressive (successful psychopath). Second, individuals with callousness lack empathy, which is an essential mechanism that propels pro-social behavior (Eisenberg, Eggum, \& DI Giunta, 2010).

Thus the following questions will be answered.

$>\quad$ To what extent will pro-social behavior be related to aggressive behavior and $\mathrm{CU}$ traits?

$>$ To what extent will CU trait be related to aggressive behavior?

$>$ To what extent will pro-social behavior be related to aggressive behavior if $\mathrm{CU}$ traits are not controlled?

\section{Method}

\subsection{Participants}

Sixty-five (65) primary school pupils comprising of 30 primary pupils (mean age $=10.50, S D=1.07$ ) and 35 primary 2 pupils (mean age $=6.02, S D=.66$ ) participated in the study. The participants' classes were randomly selected from their levels (one class for each level) and all the pupils present on the day of the study participated in the study. All the participants were of Igbo ethnic origin and reside in Nkpor-Idemili North Urban Settlement of Anambra State Nigeria.

\subsection{Instruments}

Child Behavior Scale - This is a 17 items teacher report questionnaire design to assess two dimensions of child's behavior: aggressive with peers and pro-social with peers (Ladd \& Profilet, 1996). 9 items measure aggressive with peers: "Threatens classmates, Taunts and teases classmates". And 8 items measures pro-social with peers: "Seems concerned when classmates are distressed; is kind towards classmates". The response ranged from $0=$ not true to 2 often true. Higher scores in each of the subscale indicate the higher manifestation of the behavior. Cadd and Profilet (1996) found alphas of .95 and .92 for the aggressive and pro-social subscales respectively. The Cronbach's alpha for the present study were .92 and .81 for the aggressive and pro-social 
subscales.

Inventory of callous-unemotional (ICU) - The teacher report version of ICU was used in this study (Frick, 2004). The scale contains 22 items which were rated on a four-point scale ranging from $0=($ not at all true) to 3 $=$ (definitely true). 12 items are reversed during scoring. The Inventory has three subscales: uncaring $=8$ items, callousness $=8$ items and unemotional $=6$ items. Essau et al. (2006) found Cronbach's alpha of .81 for total CU and $.81, .80$ and .53 for uncaring, callousness and unemotional respectively. The Cronbach alpha for the present study is .91 for the total scale and $.85, .86, .70$ for callous, uncaring and unemotional respectively.

\subsection{Procedure}

The school administrator and the parent-teacher Association (PTA) chairperson gave consent for the study. The pupils were not directly involved. The teachers were given the copies of the questionnaire for each of the pupils in their class and were instructed to assess the students based on their behavior in the past two months of the term. It took the teachers 3 days to complete questionnaire forms.

\subsection{Design/Statistics}

The study adopted a predictive design and hierarchical regression was used to test the main hypotheses.

\section{Results}

The result in Table 1 showed that pro-social measure correlated negatively with aggressive behavior $r(1,64)$ $=-.30, p<.05$; callousness, $r(1,64)=-.59, p<.01$; uncaring $r(1,64)=-.51, p<.01$; unemotional $r(1,64)=-.33$, $p<.05$ and CU $r(1,64)=-.60, p<.01$. Aggression correlated positively with callousness $r(1,64)=.44, \mathrm{p}<.01$; uncaring $r(1,64)=.35, p<.05$, CU $r(1,64)=.39, p<.05$, but unemotional was not significantly correlated with aggressive behavior $r(1,64)=.08, p>.05$.

\section{Table 1}

Pearson r correlation coefficient for the independent factors

\begin{tabular}{lllllll}
\hline \multicolumn{1}{c}{ Factors } & \multicolumn{1}{c}{1} & 2 & 3 & 4 & 5 & 6 \\
\hline Pro-social & 1 & & & & & \\
2. Aggression & $-30^{*}$ & 1 & & & & \\
3. Callousness & $-.59^{* *}$ & $.44^{* *}$ & 1 & & & \\
4. Uncaring & $-.51^{* *}$ & $.35^{*}$ & $.64^{*}$ & 1 & & \\
5. Unemotional & $-.33^{*}$ & .08 & $.45^{* *}$ & $.46^{* *}$ & 1 & \\
6. CU & $-.60^{* *}$ & $.39^{*}$ & $.88^{*}$ & $.88^{* *}$ & $.68^{*}$ & 1 \\
\hline Note. ${ }^{*} p<.05,{ }^{* *} p<.01$ & & & & & &
\end{tabular}

Table 2

Hierarchical regression for pro-social behavior and aggression when CU traits are not controlled

\begin{tabular}{|c|c|c|c|c|}
\hline Predictor & $\mathrm{R}^{2}$ & $F^{2}$ & $F$ & Beta \\
\hline Model 1 & .09 & .10 & $6.28 *$ & \\
\hline Pro-social & & & & $-.30 *$ \\
\hline Model 2 & .23 & .30 & $4.37 *$ & \\
\hline Pro-social & & & & -.05 \\
\hline Callousness & & & & $-38 *$ \\
\hline Uncaring & & & & .17 \\
\hline Unemotional & & & & -.19 \\
\hline Model 3 & .09 & .10 & $6.28 *$ & \\
\hline Pro-social & & & & $-.30 *$ \\
\hline Model 4 & .12 & .14 & $5.84 *$ & \\
\hline Pro-social & & & & -.11 \\
\hline ICU & & & & $.33 *$ \\
\hline
\end{tabular}


The hierarchical regression (see Table 2) showed that pro-social behavior could predict aggression when subscales of CU and total CU traits were controlled (see model 1 and 3 in Table 2) but when CU traits were not controlled the strength of pro-social behavior to predict aggression was not significant (see models 2 and 4 Table 2). The changes in $R^{2}$ were significant for both controlled conditions. When $C U$ traits were added to the models the difference between $\mathrm{R}^{2}$ in models 1 and 2 was .14, $p<.05$, while that of models 3 and 4 was $.07, p<.05$. These showed the strength of $\mathrm{CU}$ traits over pro-sociality in predicting aggression.

\section{Discussion}

The study investigated whether CU traits will predict and influence aggressive behavior over and above pro-social behavior. The results indicated that firstly, pro-social behavior is negatively correlated with aggressive behavior and CU traits. While aggressive behavior is positively correlated with $\mathrm{CU}$ traits. These findings are in accord with previous related studies (Diener \& Kim, 2004; Nelson \& Crick, 1999) which found that pro-social behavior is negatively linked to aggressive behavior and negatively related to CU traits (Flynn et al., 2015; White, 2013). Also aggressive behavior is positively associated with CU traits (Frick et al., 2014, Nwafor et al., 2015).

Second, the effect of hierarchical regression showed that when CU traits were not held, pro-social behavior do not significantly predict aggressive behavior. This finding is in agreement with the previous studies that high $\mathrm{CU}$ traits predict the severity and persistent of aggressive behavior in individual than when the CU trait is low (Frick \& Dickens, 2006; Frick et al., 2014; Kahn et al., 2012; Nwafor et al., 2015). The result showed that the callousness and total CU particularly predicted aggressive behavior, even when pro-social behavior is present in an individual. The high present of $\mathrm{CU}$ traits might explain the reason while some individual are described as "bi-strategic" (Gao \& Raine, 2010; Hawley, 2003). In a bi-strategic individual with CU traits the pro-social behavior may be suppressed by the aggressive behavior because of the obvious individual and societal costs of aggressive behaviors (Coie \& Dodge, 1998; Scott, Knapp, Henderson, \& Maughan, 2001). Also Callousness psychopaths lack empathy which is an essential mechanism for the manifestation of pro-social behavior (Eisenberg, Eggum, \& Di Giunta, 2010).

\subsection{Limitation of the Study}

The main limitation of the present work is the choice of using only teacher's report questionnaire in collecting data for the ingredients. The research conceptualized pro-social and aggressive behavior from the one-dimensional perspective, this may not cover the multi-dimension interest, and this may limit the abstraction of the determination. Observational method, other informants (parents) or interview or experiment could have added more validity to the data for analysis (Wildeboer, 2015). Also, developmental studies prefer the longitudinal design to capture the trajectories of change across different stages of the lifespan. Although the present study attempts manage this by taking participants from different stages or level of primary schools, but within group reports are always more reliable than between group design in the developmental studies.

\subsection{Implication}

The result threw more light on what seem to be persistent or stubborn aggressive behavior in some children. This may be explained to be a result of the presence of CU traits which inhibits empathy. Thus, even when the individual manifests pro-social behavior, the present of the psychopathic trait $(\mathrm{CU})$ may inhibit the individual power to contain the urge for aggressive acts. This fact has implication for policy makers, schools, and families. Once a child continually manifests significant aggressive acts from infancy across early and middle childhood caregivers may intervene by paying special attention and seeking help from professionals. This may call for designing special programs targeted at improving the pro-social act and cutting both the CU and aggressive behavior. 


\section{Conclusion}

Childhood is a very significant point in human lifespan development. This is because most of the behaviors found in adult humans originated during the childhood and certainly influence the subsequent behavior manifestations (normal or abnormal) throughout the lifespan (Frick et al., 2014; Wildeboer, 2015). Therefore, human developmental sciences devote time in understanding the trajectories of behavior throughout the lifetime. The hope is that through research, some prophylactic measures could be advanced against abnormal or undesirable behaviors and traits such as aggressive behavior and CU traits, while normal or desirable behavior such as pro-social behavior would be encouraged and sustained. This study utilizes empirical technique and found that CU traits (developmental psychopathic traits) hindered the buffer influence of pro-social behavior on aggressive behavior. Research has supported that CU traits are responsible for the severity and persistence of conduct problems in children (Frick et al., 2014; White, 2013). This knowledge demands that parents and other caregivers involved in children upbringing should take extra measure on their ward's welfare especially when they manifest persistent aggressive behavior. This is because CU traits may be implicated and if that is the case effort (such as increased parental monitoring, change of parenting style, encouraging pro-social and normal tendencies and consulting of professionals: see; Fontaine, Rijsdijk, McCrory, \& Viding, 2010; Head, 2008) should be made to control them so that the subsequent developmental stage would not be adversely marred. Perhaps, if this is achieved the future hope of the society (the children) will be certain and secured.

Acknowledgement: This Paper was presented at the Society for the study of the African Child (SOSAC) conference on 10th November, 2015 Enugu, Nigeria.

\section{References}

Amato, P. R., \& Cheadle, J. E. (2008). Parental divorce, mental conflict and children's behavior problems: a comparison of adopted and biological children. Social Forces, 86(3), 1139-1161. http://dx.doi.org/10.1353/sof.0.0025

Caprara, G. V., Barbaranelli, C., \& Pastorelli, C. (2001). Pro-social behavior and aggression in childhood and pre-adolescence. In A. C. Bohart \& D. J. Stipek (Eds.), Constructive and destructive behavior: Implications for family, school, and society (pp. 187-203). Washington, DC: American Psychological Association. http://dx.doi.org/10.1037/10433-009

Carlo, G., Knight,G. P., McGinley, M., Zamboanga, B. L., \& Jarvis, L. H. (2010). The multidimensionality of pro-social behaviors and evidence of measurement equivalence in Mexican American and European American early adolescents. Journal of Research on Adolescence, 20(2), 334-358. http://dx.doi.org/10.1111/j.1532-7795.2010.00637.x

Cassidy, K. W., Werner, R. S., Rourke, M., Zubernis, L. S., \& Balarman, G. (2003). The relationship between psychological understanding and positive social behaviors. Social Development, 12, 198-221. http://dx.doi.org/10.1111/1467-9507.00229

Clark, K. E., \& Ladd, G. W. (2000). Connectedness and autonomy support in parent-child relationships: Links to children's socioemotional orientation and peer relationships. Developmental Psychology, 36(4), 485-498. http://dx.doi.org/10.1037/0012-1649.36.4.485

Coie, J. K., \& Dodge, K.A. (1998). Aggression and antisocial behavior. In W. Damon \& N. Eisenberg (Eds.), Handbook of child psychology (5th ed., Vol. 3, pp. 779-861). NY: John Wiley \& Sons.

de Guzman, M. R. T., Edwards, C. P., \& Carlo, G. (2005). Pro-social behaviors in context: A study of the Gikuyu children of Ngecha, Kenya. Journal of Applied Developmental Psychology, 26, 542-558. http://dx.doi.org/10.1016/j.appdev.2005.06.006

Diener, M. L., \& Kim, D. Y. (2004). Maternal and child predictors of preschool children's social competence. Applied Developmental Psychology, 25, 3-24. http://dx.doi.org/10.1016/j.appdev.2003.11.006

Dwairy, M. (2009). Parenting and adolescent's psychological adjustment: Toward a systemic approach in 
Pro-social and aggressive behaviors among school children: The role of callous-unemotional traits

parenting research. The Open Family Studies Journal, 2, 73-87. http://dx.doi.org/10.2174/1874922400902010066

Eisenberg, N., Eggum, N. D., \& Di Giunta, L. (2010). Empathy related responding: Associations with pro-social behavior, aggression, and intergroup relations. Social Issues and Policy Review, 4, 143-180. http://dx.doi.org/10.1111/j.1751-2409.2010.01020.x

Eisenberg, N., Fabes, R. A., \& Spinrad, T. L. (2006). Pro-social development. In W. Damon, R. M. Lerner, \& N. Eisenberg (Eds.), Handbook of child psychology: Social, emotional, and personality development (Vol. 3, pp. 646-718). New York: Wiley.

Eisenberg, N., Fabes, R. A., Murphy, B. C., Karbon, M., Smith, M., \& Maszk, P. (1996). The relations of children's dispositional empathy- related responding to their emotionality, regulation, and social functioning. Developmental Psychology, 32, 195-209. http://dx.doi.org/10.1037/0012-1649.32.2.195

Eisenberg, N., Guthrie, I. K., Murphy, B. C., Shepard, S. A., Cumberland, A., \& Carlo, G. (1999). Consistency and development of pro-social dispositions: A longitudinal study. Child Development, 70, 1360-1372. http://dx.doi.org/10.1111/1467-8624.00100

Essau, C. A., Sasagawa, S., \& Frick, P. J. (2006). Callous-unemotional traits in community sample of adolescent. Assessment, 13, 454-469. http://dx.doi.org/10.1177/1073191106287354

Ferdinand, R. F., Van der Ende, J., \& Verhulst, F. C. (2007). Parent-teacher disagreement regarding behavioral and emotional problems in referred children is not a risk factor for poor outcome. European Child and Adolescent Psychiatry, 16, 121-127. http://dx.doi.org/10.1007/s00787-006-0581-0

Flynn, E., Ehrenreich, S. E., Beron, K. J. \& Underwood, M. K. (2015). Pro-social behavior: long-term trajectories and psychosocial outcomes. Social Development, 24(3), 462-482. http://dx.doi.org/10.1111/sode. 12100

Fontaine N. M. G., Rijsdijk F. V., McCrory E. J. P., \& Viding E. (2010). Etiology of different developmental trajectories of callous-unemotional traits. Journal of the American Academy of Child \& Adolescent Psychiatry, 49, 656-664. http://dx.doi.org/10.1016/j.jaac.2010.03.014

Frick P. J. (2004). The inventory of callous-unemotional traits (Unpublished rating scale). Department of Psychology, University of New Orleans. New Orleans, USA.

Frick P. J., \& Dickens C. (2006). Current perspectives on conduct disorder. Current Psychiatry Reports, 8, 59-72. http://dx.doi.org/10.1007/s11920-006-0082-3

Frick, P. J., Ray, J. V., Thornton, L. C., \& Kahn, R. E. (2014). Can callous-unemotional traits enhance the understanding, diagnosis, and treatment of serious conduct problems in children and adolescents? A comprehensive review. Psychological Bulletin, 140(1), 1-57. http://dx.doi.org/10.1037/a0033076

Gao, Y., \& Raine, A. (2010). Successful and unsuccessful psychopaths: A neurobiological model. Behavioral Sciences \& the Law, 28, 194-210. http://dx.doi.org/10.1002/bsl.924

Gill, K. L., \& Calkins, S. D. (2003). Do aggressive/destructive toddlers lack concern for others? Behavioral and physiological indicators of empathic responding in 2-year-old children. Development and Psychopathology, 15, 55-71. http://dx.doi.org/10.1017/S095457940300004X

Grusec, J. E (2011) socialization processes in the family: social and emotional development. Annual review of Psychology, 62, 243-269. http://dx.doi.org/10.1146/annurev.psych.121208.131650

Hare, R. D., \& Neumann, C. S. (2008). Psychopath as a clinical and empirical construct. Annual Review of Clinical Psychology, 4, 217-246. http://dx.doi.org/10.1146/annurev.clinpsy.3.022806.091452

Hawley, P. H. (2003). Strategies of control, aggression, and morality in preschoolers: An evolutionary perspective. Journal of Experimental Child Psychology, 85, 213-235. http://dx.doi.org/10.1016/S0022-0965(03)00073-0

Head S. E. (2008). Parental influences on children's callous-unemotional traits (Published masteral thesis). University of Canterbury, Canterbury, UK. Retrieved from http://ir.canterbury.ac.nz/bitstream/10092/2272/1/thesis_fulltext.pdf

Hodges, E. V. E., \& Perry D. G. (1996). Victims of peer abuse: An overview. Journal of Emotional and Behavioral problems, 5, 23-28.

Hughes, C., \& Dunn, J. (2000). Hedonism or empathy? Hard-to-manage children's moral awareness and links 
Nwafor, C. E., Anazonwu, C. O., Okafor, O. C., \& Obi-Nwosu, H.

with cognitive and maternal characteristics. British Journal of Developmental Psychology, 18, 227-245. http://dx.doi.org/10.1348/026151000165661

Kahn, R. E., Frick, P. J., Youngstrom, E., Findling, R. L., \& Youngstrom, J. K. (2012). The effects of including a callous- unemotional specifier for the diagnosis of conduct disorder. Journal of Child Psychology and Psychiatry, 53, 271-282. http://dx.doi.org/10.1111/j.1469-7610.2011.02463.x

Kokko, K., Tremblay, R. E., Lacourse, E., Nagin, D. S., \& Vitaro, F. (2006). Trajectories of pro-social behavior and physical aggression in middle childhood: Links to adolescent school dropout and physical violence. Journal of Research on Adolescence, 16(3), 403-428. http://dx.doi.org/10.1111/j.1532-7795.2006.00500.x

Ladd, G. W., \& Profilet, S. M. (1996). The child behavior scale: A teacher-report measure of young children's aggressive, withdrawn, and pro-social behaviors. Developmental Psychology, 32(6), 1008-1024. http://dx.doi.org/10.1037/0012-1649.32.6.1008

McGinley, M., \& Carlo, G. (2006). Two sides of the same coin? The relations between pro-social and physically aggressive behaviors. Journal of Youth and Adolescence, 36, 337-349. http://dx.doi.org/10.1007/s10964-006-9095-9

Mcleod, B. D, Weisz, J. R., \& Woods, J. J. (2007). Examining the association between parenting and childhood depression. A meta-analysis. Clinical Psychology Review, 27(8), 986-1003. http://dx.doi.org/10.1016/j.cpr.2007.03.001

Nantel-Vivier, A., Pihl, R. O., \& Tremblay, R. (2010). Developmental association of pro-social behaviors with aggression, anxiety, and depression from infancy to pre-adolescence. The American Journal of Psychiatry, 24, 1135-1144.

Nelson, D. A., \& Crick, N. R. (1999). Rose-colored glasses: Examining the social information-processing of pro-social young adolescents. Journal of Early Adolescence, 19, 17-38. http://dx.doi.org/10.1177/0272431699019001002

Nwafor C. E., Onyeizugbo, E. U., \& Anazonwu, C. O. (2015). Does gender moderate the relationship between callous-unemotional traits and physical aggression? The Spanish Journal of Psychology, 18(82), 1-9. http://dx.doi.org/10.1017/sjp.2015.86

O’Campo, P., Burke, J., Peak, G., McDonnell, K., \& Gielen, A. (2005). Uncovering neighborhood influences on intimate partner violence using concept mapping. Journal of Epidemiology and Community Health, 59(7), 603-608. http://dx.doi.org/10.1136/jech.2004.027227

Penner, L. A., Fritzsche, B. A., Craiger, J. P., \& Freifeld, T. S. (1995). Measuring the pro-social personality. In J. N. Butcher \& C. D. Spielberger (Eds.), Advances in personality assessment (Vol. 10, pp. 147-163). Hillsdale, NJ: Lawrence Erlbaum Associates, Inc.

Perry, D. G., Hogdes E. V. E., \& Egan S. K. (2001). Determinants of chronic victimization by peers: A review and a new model of family influence. In J. Juvonen \& S. Graham (Eds.), Peer harassment in school: The plight of the vulnerable and victimized (pp. 73-104). New York, NY: Guilford press.

Porter, S., \& Woodworth, M. (2006). Psychopathy and aggression. In C. Patrick (Ed.), Handbook of psychopathy (pp. 481-494). New York: Guilford Press.

Rothbaum, F., \&Weisz, J. R. (1994). Parental caregiving and child externalizing behavior in non-clinical sample: A meta-analysis. Psychological Bulletin, 116, 55-74. http://dx.doi.org/10.1037/0033-2909.116.1.55

Scott, S., Knapp, M., Henderson, J., \& Maughan, B. (2001). Financial cost of social exclusion: follow up study of antisocial children into adulthood. British Medical Journal, 323(7306), 191-194. ttp://dx.doi.org/10.1136/bmj.323.7306.191

White, B. A. (2013).Who cares when nobody is watching? Psychopathic traits and empathy in pro-social behaviors. Personality and Individual Differences. http://dx.doi.org/10.1016/j.paid.2013.08.033

Wildeboer, A., Thijssen, S., van IJzendoorn, M. H., van der Ende, J., Jaddoe, V. W. V, Verhulst F.C., ...Bakermans-Kranenburg, M. J. (2015). Early childhood aggression trajectories: Associations with teacher-reported problem behavior. International Journal of Behavior development, 39(3) 221-234. http://dx.doi.org/10.1177/0165025414562239 